\title{
SOCIO-ECONOMIC AND MEDICINAL IMPORTANCE OF EUCALYPTUS TREES: A CRITICAL REVIEW
}

Oke R.A. ${ }^{1}$, Adetola O.O. ${ }^{2}$, Owoeye Y.T. ${ }^{3}$, Akemien N.N. ${ }^{4}$, Adaaja B.O. ${ }^{5}$, Bakpolor V.R. ${ }^{6}$, Murtala M.O. ${ }^{7}$

Received: 2021-06-09

Accepted: 2021-07-06

DOI: http://doi.org/10.46489/gpj.2021-1-2-3

Abstract. Pollution is a great issue of the environment that is gaining global attention currently because industrial development has disturbed the ecosystem of the world and depleting the ozone. It has resulted in global warming and increased the temperature, which has changed the climate at different levels globally. According to a world report, about $25 \%$ of forest land is required for ecosystem favourability. There are so many trees which are grown in the world. Among these trees, Eucalyptus is very popular and was first grown in Australia. This plant has both economic and health benefits. Pharmacologists converted this plant into medicine for different health disease control in the world. Essential Oil squeezed from the leaf and bark of the tree and leaves also possess great benefits. The well-known diseases are blood pressure, diabetes, Arthritis, plague, Cough etc., while it is also used for mosquitoes, termites, and white ants control. The plant also has its disadvantage; it decreases the water table and disturbs the tube well system. Those plants need much water, so they compete with other plants in the area and affect the size of the plant. The major objective was to review the socioeconomic and medicinal value of the eucalyptus tree. Total 19 articles were downloaded from the net and reviewed in depth. The result indicates that the Eucalyptus tree has many socioeconomic and medicinal values.

Keywords: ecosystem disturbance, ecosystem favourability, Eucalyptus, Essential Oil, value of the eucalyptus tree.

\footnotetext{
${ }^{1}$ Oke R.A., Forestry Research Institute of Nigeria, P.M.B 5054 Jericho Hills, Ibadan, Nigeria, ORCID: https://orcid.org/0000-0003-0129-0145

${ }^{2}$ Adetola O.O., Forestry Research Institute of Nigeria, P.M.B 5054 Jericho Hills, Ibadan, Nigeria, e-mail: ajibols03@hmail.com, ORCID: https://orcid.org/0000-0002-4011-2686

${ }^{3}$ Owoeye Y.T., Forestry Research Institute of Nigeria, P.M.B 5054 Jericho Hills, Ibadan, Nigeria, ORCID: https://orcid.org/0000-0003-3049-9829

${ }^{4}$ Akemien N.N., Forestry Research Institute of Nigeria, P.M.B 5054 Jericho Hills, Ibadan, Nigeria, ORCID: https://orcid.org/0000-0002-3878-3210

${ }^{5}$ Adaaja B.O., Forestry Research Institute of Nigeria, P.M.B 5054 Jericho Hills, Ibadan, Nigeria, ORCID: https://orcid.org/0000-0002-9373-6329

${ }^{6}$ Bakpolor V.R., Forestry Research Institute of Nigeria, P.M.B 5054 Jericho Hills, Ibadan, Nigeria, ORCID: https://orcid.org/0000-0001-7098-2108

${ }^{7}$ Murtala M.O., Forestry Research Institute of Nigeria, P.M.B 5054 Jericho Hills, Ibadan, Nigeria, ORCID: https://orcid.org/0000-0001-8473-0622
} 


\section{INTRODUCTION}

Eucalyptus is a popular plant that is used for a different purposes. As a medicine, we used it for different ailments besides its economic value. Several Farmers grow this plant mostly in waterlogged areas. We primarily use the wood of the eucalyptus in the furniture industries because of a shortage of poplar wood in the world. Its wood is tough and patchy, and the farmer mainly used for fuelwood, while this wood is also used in the furniture industry. Their charcoals are commonly used and give more energy to them than the poplar wood. They mostly used this plant for the control of waterlogging. They are mostly planted on high $\mathrm{Ph}$ value soil. Shechem was replaced by eucalyptus because of a white ant attack. The majority of Shechem are observed on the river, which the white ant damaged. By canal irrigation, white ants were spread into farmland, and it destroys the crops and other plants of the farming community. Among this poplar plant is the sugar cane crop known in several parts of the globe. In some places, the sugarcane crop has been removed from the cropping pattern. The wood of the eucalyptus is also used as an electrical pole in the world.

They naturally found a few species in the Philippines, Papua New Guinea, Indonesia and Timor. Several ecological conditions support the growth of Eucalyptus, some hardy species growing in semi-arid areas, while others can grow on marshy and swampy sites. Eucalypts also grow under various soils, including fertile loamy soils, infertile sands and heavy clays (Boland et al., 2006). The population pressure in Ethiopian highlands and other parts of Africa has led to a change in land use or land cover and establishment of woodlots, so plantation of exotic tree species such as Eucalyptus has long been advocated as a strategy for relieving pressure on indigenous forests and woodlands (Boland et al., 2006). The eucalyptus tree has provided foresters and farmers with a valuable resource of fastgrowing species that can grow under a wide range of conditions based on the particular species being used. Factors that drive farmers to plant Eucalyptus include increasing demand for wood products in the market, unavailability of wood on-farm, high rate of biomass production, easy to cultivate, and wider adaptability, no palatability to livestock (Mekonnen \& Aticho, 2011).

Some of the environmental and socioeconomic benefits of Eucalyptus species include fuelwood production (for fire), pole production, building, medicinal purposes (e.g. blue gum used to treat flu, the common cold), timber productions (Derba, 2016). In contrast, Eucalyptus has been having undesirable ecological qualities such as depletion of soil water and nutrients, intensive competition with native flora for resources, unsuitability for erosion control, production of an allelopathic chemical that inhibit the growth of other plants and provision of inadequate food and habitat for wildlife (Haileab, 2010).

\section{MATERIAL AND METHODS}

A total of 19 articles were downloaded from the net and were reviewed severally. The abstract and conclusion were drawn with practical experience in addition to this article writing.

\section{NOMENCLATURE}

Table 1.

Botanical Classification of the Plant

\begin{tabular}{|l|l|}
\hline Kingdom & Plantae \\
\hline Clade & Tracheophytes \\
\hline Clade & Eudicots \\
\hline Clade & Rosids \\
\hline Order & Myrtales \\
\hline Family & Myrtaceae \\
\hline Sub family & Myrtoideae \\
\hline Tribe & Eucalypteae \\
\hline Genus & Eucalyptus \\
\hline
\end{tabular}




\section{THE SPREAD OF EUCALYPTUS AND ITS ADAPTATIVE FEATURES}

Eucalypts planting outside its native environment of Australia started in 1904 in Brazil. Today Eucalyptus plantations cover at least 12 million ha throughout the tropical zone, $90 \%$ of which have been established since 1955 (Turnbull, 1999). Concerns were raised around this time about the adverse effects of these plantations on the environment. Eucalyptus planting on farmlands, stream banks and catchment areas was banned because of these adverse effects. Eucalyptus was used in plantations outside its natural distributions area over 200 years ago in Europe. Native to Australia, it reached South Africa, Nigeria and Brazil between the late nineteenth century and early twentieth century. This species is used in reforestation or afforestation program. E.globulus and E. camaldulenesis are the two species that grow anywhere in the world (Getachew, 2016). Since then, the plant was expanded to all corners of the country, and concerns were felt around this time about the adverse effects of the plantation environment. Eucalyptus has increased in importance globally because many species of eucalyptus can improve conditions in treeless areas. Eucalyptus has raised people's livelihood by providing several ends uses, and many farmers continue to plant and use them as building materials, fuelwood and charcoal making. Locally they are also found in shelterbelt, shady groves in and around the village, churches and other dwellings. They also make up a significant source of honey and their leaves as a traditional medicine to fight flu and fever.

The Rapid growth rates in eucalypts have been attributed to indefinite shoots (i.e. a growing tip that produces pairs of leaves at irregular intervals) and do not have resting buds. With these characteristics, eucalypts can grow both in height and length infinitely under favourable conditions. When a branch or shoot is damaged, the "naked bud" or the growing tip, which can further produce a branch of following order, immediately becomes the central bud. As the upper crown increase in height, the lower parts of the trunk are built up, resulting in large volumes of wood per hectares (FAO, 1979). Eucalyptus, a very successful tree, adapts to a variety of habitats with evolutionary adaptive features such as tolerance of severe periodic moisture stress through xeromorphic leaves, stomata close when water potential deficits in the leaf are high, hairy juvenile leaves (some species), volatile leaf oils, deciduous in the dry season (few species), low soil fertility tolerance through the adaptive capacity to soil with low nitrogen and phosphorus content. Specialized nutrients intakes system of eco-and endo-mycorrhizae that increase phosphorus uptake mainly and also zinc, copper, ammonium, tolerance of fire damage through lignotubers (underground organs) thick barks, dormant bud system and tolerance of insect damage by oils and phenolic compounds have been developed by the plant (Haileab, 2010). Eucalyptus usually matures within 5-25 years. Tending of Eucalyptus coppices is done to generate second and subsequent parents of Eucalyptus. Coppices are derived from dormant buds on the cambium of cut trees. Dominant Coppice shoots with a good attachment to the stump should be selected for retention (Kaumi, 1983).

Shoots that are chosen should be as deep down the stump as possible and as wide apart as practicable. Windward shoots are preferred. The root crowns of certain Eucalyptus species are lingo tuberous, which facilitate coppice production. Lignotubers are swellings at the stem base that comprise a mass of tissue that assist the tree to sprout should the main stem die. E.delegatensis and E. regnans species hardly regenerate from coppices (Konuche, 1989). Even though the rural livelihood index of Eucalyptus have been established, E.globulus are 
undermined by several scientists and communities because of the belief that "there are significant negative environmental challenges associated with Eucalyptus trees". Most criticisms draw their strength from a range of technical, ecological, and socio-economic arguments (FAO, 1988).

\section{SOCIO-ECONOMIC AND HEALTH VALUES OF EUCALYPTUS}

In the countries where $85 \%$ of the population depends on subsistence farming, which is usually outdated Agriculture, poverty increase and food insecurity become a significant concern for policymakers and government. Eucalyptus significantly contributes to household livelihood improvement, which reduces poverty significantly. Eucalyptus is the largest nonagricultural source of household income (Jigger \& Pender, 2000). Eucalypts trees have many distinctive characteristics compared to other indigenous trees. Farmers grow eucalyptus trees to fulfill scarcity of fuelwood and construction materials.

Eucalyptus plantation had prevented financial crisis for many poor farmers on land not suited to sustainable agricultural practice. In many developing countries, the area of private planting was much greater than that planted by government departments or industries (Gessesse \& Tekilu, 2011). The plantations have increased job opportunities both in the plantations and processing industries (FAO, 1985). Eucalyptus species are economically important tree species; hence, they are very useful. Eucalyptus is used for fuelwood, charcoal, timber, poles, posts, mine props, poly-wood, paper pulp, fiberboard, tanning, oil, shade \&shelter, ornamental purpose $\&$ as a source of nectar for honey production (Haileab, 2010). The Eucalyptus species is very marketable, which gives it a competitive edge over other tree species and contributes to the growth of the national economy (Jaleta et al., 2016).
Originally native to Australia, eucalyptus trees are now grown worldwide and used for medicinal purposes. Their healing potential is attributed to eucalyptus oil, which is made from the tree's oval-shaped leaves. They are dried, crushed, and distilled to give up the essential oil.

The extracted oil must be diluted before being taken as medicine. Nine benefits of eucalyptus oil are discussed below. Eucalyptus oil has been used to relieve coughing. Currently, most over-thecounter cough medications have eucalyptus oil major active ingredient. Vicks Vapo-Rub, for instance, contains about 1.2 per cent eucalyptus oil and other cough suppressant ingredients. The popular rub is applied to the chest and throat to relieve cough symptoms from the common cold or flu. Inhaling vapour made with the essential oil can loosen mucus so that when you do cough, it's expelled. Using a rub containing eucalyptus oil will produce the same effect. Mosquitoes and other biting insects carry diseases that can be dangerous to our health. Avoiding their bites is our best defence. DEET sprays, a popular repellant, are made with strong chemicals. Alternatively, for those who are not able to use DEET, botanical compounds can repel the pests. The Australian aborigines used eucalyptus leaves to treat wounds and prevent infection. Today the diluted oil may still be used on the skin to fight inflammation and promote healing. You can purchase creams or ointments that contain eucalyptus oil. These products may be used on minor burns or other injuries that can be treated at home. Respiratory conditions such as asthma and sinusitis may be helped by inhaling steam with added eucalyptus oil. The oil reacts with mucous membranes, not only reducing mucus but helping loosen it so that you can cough it up. It's also possible that eucalyptus blocks asthma symptoms. For people who are allergic to eucalyptus, it may worsen their asthma. More research is needed to determine how eucalyptus 
affects people with asthma. Eucalyptus oil has the potential as a treatment for diabetes. Although we know little, experts believe it may play a role in lowering blood sugar in people with diabetes. Researchers have not yet figured out how the essential oil works. However, until more is known, the scientific community recommends careful blood sugar monitoring for people using diabetes medication with eucalyptus oil. The anti-inflammatory properties of eucalyptus can reduce symptoms of herpes. Applying eucalyptus oil to a cold sore can ease pain and speed up the healing process.

\section{SHADING EFFECTS OF EUCALYPTUS ON CROPS}

Due to their rapid growth, exotics trees plantation are usually taller than other plants of same age, and their shade may affect nearby crops by reducing the sunlight needed for growth. Because of shading and competition for water, the yields from crops close to Eucalyptus plantations are most times not as good as they are further away from the edge (Demel, 2000). Therefore, eucalyptus trees often reduce crop yields on plots next to wood lots or rows of trees and the allopathic effects of eucalyptus and competition for nutrients when planted next to food crops or intercross with cereals or vegetables may lead to a loss in food crop production that may affect household food security and income. Allelopathy is the release of chemicals from leaves or litters that inhibit the germination or growth of other plant species and consequently reduce the output of crops (FAO, 1985).

Table 2.

Noted ecological effects of Eucalyptus

\begin{tabular}{|c|c|c|}
\hline Effects & Positive effects & Negative effects \\
\hline $\begin{array}{l}\text { Biomass } \\
\text { production }\end{array}$ & $\begin{array}{l}\text { Short term options for the provision of critically } \\
\text { required biomass is the planting of fast-growing } \\
\text { eucalyptus. }\end{array}$ & The scarcity of Land is a constraint \\
\hline \multirow{2}{*}{$\begin{array}{l}\text { Effects on soil, } \\
\text { nutrient } \\
\text { depletion and } \\
\text { top soil } \\
\text { retention }\end{array}$} & $\begin{array}{l}\text { On degraded hillsides and wastelands, the net soil } \\
\text { nutrient contribution of Eucalyptus through leaf } \\
\text { litter is likely to be positive. }\end{array}$ & $\begin{array}{c}\text { Eucalyptus trees deplete soil nutrients } \\
\text { Needed by agricultural crops, } \\
\text { however the spatial magnitude of } \\
\text { depletion is not known. }\end{array}$ \\
\hline & $\begin{array}{l}\text { Good potential for topsoil retention on degraded } \\
\text { hillside. }\end{array}$ & $\begin{array}{l}\text { The ability of Eucalyptus to provide } \\
\text { organic matter is questionable. }\end{array}$ \\
\hline $\begin{array}{l}\text { Allelopathic } \\
\text { effects }\end{array}$ & $\begin{array}{l}\text { Rainfall may decrease or negate the allelopathic } \\
\text { effects of trees on crop. }\end{array}$ & $\begin{array}{l}\text { Allelochemicals negatively influence } \\
\text { agricultural production and are a } \\
\text { more significant factor in dry regions. }\end{array}$ \\
\hline \multirow{2}{*}{$\begin{array}{l}\text { Hydrological } \\
\text { impact }\end{array}$} & $\begin{array}{l}\text { In regions with erratic and severe rainfall the } \\
\text { ability to take up large quantities of water may } \\
\text { reduce runoff, flooding and water logging. }\end{array}$ & $\begin{array}{l}\text { Eucalyptus may complete water away } \\
\text { from agricultural crops decreasing } \\
\text { agricultural output up to } 10 \text { meters } \\
\text { away from trees plantation. }\end{array}$ \\
\hline & $\begin{array}{l}\text { On previously barren slopes, tree cover may } \\
\text { reduce erosion and gully formation caused by } \\
\text { rainfall. }\end{array}$ & $\begin{array}{c}\text { Wide-scale hydrological impacts are } \\
\text { uncertain. }\end{array}$ \\
\hline
\end{tabular}

Source: Jigger and Pender, 2000

\section{CONCLUSION}

It is known that natural forests supply a wide variety of benefits that is very important or useful to the local communities in the long term, plantation may still supply more significant quantities of materials within a short time. Advantages of Eucalyptus include industrial wood, poles, timber, fuelwood, bee forage, essential oils, and several environmental services such as windbreaks, erosion control, buffer to natural forests, flood control, and climate 
change mitigation. In addition, eucalyptus is also presently used in construction and woodwork. So, planting Eucalyptus has excellent benefits for society in improving their socio-economic livelihood and

\section{Reference}

Boland, D. J., Brooker, M. I. H., Chippendale, G. M., Hall, N. Hyland, B. P. M. and Johnson, R. D. (2006). Forest trees of Australia. Melbourne, CSIRO, Australia

Demel, T (2000). Facts and experience on eucalyptus in Ethiopia and elsewhere: ground for making wise and informed decision. Workshop on Eucalyptus Dilemma, 15 Nov, 2000

Derba, B. (2016) .Socio economic importance of selected Indigenous and Exotic Tree Species used in Dabat district, North Gonder, Ethiopia.

FAO (1979) .Eucalyptus for planting .FAO forestry and forest product study NO.11.679PP. FAO, Rome.

FAO (1985). The ecological effect of Eucalyptus. FAO. Forestry paper NO.59.FAO. Rome.

FAO. (1988). The Eucalyptus dilemma. No.26 pp. Rome, Italy.

Gessesse, D. Tekilu,E. (2011). Eucalyptus in east Africa, socio-cultural and environmental Issue, planted forest Tree Working paper 46/E Forest Management Team, FAO, Rome.

Getachew, A (2016). The impact of Eucalyptus expansion on food security In Bambasi woreda. Benishngul Gumuz regional state, western Ethiopia.

Gindaba J.2003. Water and nutrient relations of selected tree species of Ethiopia. PhD dissertation. University of Stellenbosch, South Africa. 2003; 190. 63.

Haileab, Z (2010) .Environmental socio economic implications of Eucalyptus in Ethiopia, INGil, L, Wubalem Tadesse, Tolosana, E. and Lopez, R. Processing the conference on Eucalyptus species management, History, status and trends in Ethiopia pp. 184 -205. EIAR. Adiss Ababa. regulating climate change, enhancing healthy living.

Jagger, P. Pender.J, (2000). The role of trees for sustainable management of less favored land the cause of Eucalyptus in Ethiopia, EPTD Discussion paper, No.65.

Jaleta D, Mbilinyi B. Mahoo H, Lemenih M., (2016). Eucalyptus Expansion as Relieving and Provocative Tree in Ethiopia. JAERI, 6(3): 1-12, www.sciencedomain.org.

Kaumi, S.Y.S. (1983). Four rotations of Eucalyptus yield trial. Commonwealth Forestry Review 62: $19-24$.

Konuche, P. K. A. (1989). Results of Eucalyptus species trial at Londiani.KEFRI Technical Note, No 6.

Mekonnen T, Aticho A (2011). The driving forces of Boye wetland degradation and its bird species composition, Jimma, Southwestern.Journal of Ecology and the Natural Environment. 3:365-369. 58.

Turnbull JW (1999). Eucalypt plantations. New Forests 17, 37-52. 